\title{
Koulutusjärjestelmän kehittämishaasteet aikuiskoulutukselle vai aikuiskoulutuksen kehittämishaasteet koulujärjestelmälle
}

Otsikossa esitetyt vaihtoehtoiset väittämät pitävät kumpikin paikkansa. Lisäksi näihin on sanottava, että yhteiskunta ja yksilö asettavat vielä haasteita kummallekin. Mikään järjestèlmä ei saa olla itsetarkoitus, vaan apuväline, jolla on tietty tuloksellinen tavoite. Koulutusjärjestelmän pitää pystyä antamaan sellaista koulutusta, jota yhteiskunta ja työelämä tarvitsevat. Toisaalta jokaisen yksilön tulee koulutusjärjestelmässä saada niitä valmiuksia, joita hän elämässään tarvitsee. Erityisesti hänen tulee pystyä kehittämään itseään jatkuvasti.

Aikuiskoulutuksella tulee olla selvä kytkentä koulutusjärjestelmään. Se toimii jatkokoulutuksena järjestelmän jokaisen koulutuksen päälle niin yleissivistävän kuin myös ammatillisen koulutuksen kohdalla. Yhteiskunnan ja työelämän kehittyminen sekä yksilön tarve kehittyä vaativat jatkuvaa täydennyskoulutusta, työtehtävät ja ammatit vaihtuvat, mikä aiheuttaa uudelleenkoulutuksen tarvetta. Peruskoulutusjärjestelmän mukaisessa koulutuksessa on varmasti monelle jäänyt useiden valmiuksien kohdalla aukkoja, jotka pitää voida paikata aikuiskoulutuksella.

Aikuiskoulutusjärjestelmän tulee olla sellainen, että kaikki edellämainitut tarpeet voidaan tyydyttää. Sen tulee olla mahdollisimman joustava, jotta se pystyisi täyttämään sille asetetut vaatimukset.

Laki keskiasteen koulutuksen kehittämisestä (474/78) määrää, että mahdollisuus ammatillisesti eriytyvään koulutukseen tulee järjestää kaikille peruskoulusta ja lukiosta pääseville nuorille. Tämä tarkoittaa sitä, että tulevaisuudessa tulee olemaan vähintään kahden vuoden ammatillinen peruskoulutus jokaisella. Laki määrää, että ammatillisen koulutuksen tulee sekä laadullisesti että määrällisesti vastata yhteiskunnan ja työelämän vaatimuksia sekä niissä tapahtuvia muutoksia. Tätä määräystä ei voida täydellisesti toteuttaa ilman jatko- ja täydennyskoulutusta, siis ilman aikuiskoulutusta. Joustava jatko- ja täydennyskoulutusjärjestelmä pystyy seuraamaan muuttuvia työelämän tarpeita nopeasti ja antamaan tarkoituksenmukaista koulutusta. Keskiasteen koulutusjärjestelmän mukaisten laaja-alaisten koulutusammattien päälle tarvitaan usein heti peruskoulutusvaiheen jälkeen suppeampialaista työammattiin koulutusta.

Keskiasteen koulunuudistuksen opetussuunnitelmien organisaatio mahdollistaa koulutusammatin tutkinnon joustavan suorittamisen. Koulutusammatti muodostuu oppimääristä, jotka koostuvat kursseista. Oppimäärät ja kurssit ovat tavoitteellisia kokonaisuuksia. Pitäisi kiireesti suorittaa eri koulutusammattien oppimäärien ja kurssien koordinointi ja luettelointi. Luetteloon pitäisi saada myös tiedot oppimateriaaleista. Kursseja pitää voida suorittaa "missä tahansa", myös aikuiskoulutuksena. Opintokirjasta näkyy mitä kursseja ja oppimääriä kukin on suorittanut. Mahdollisuuksia kurssien suorittamiseen ja uusimiseen pitäisi olla runsaasti. Alan vaihto helpottuisi ja koulutuksen keskeyttämiset vähenisivät, jos järjestelmästä teh- täisiin mahdollisimman joustava. Aikuiskoulutuksena pitäisi siis voida suorittaa keskiasteen peruskoulutukseen kuuluvia kursseja ja oppimääriä. Kun opetussuunnitelma ja oppimateriaali on sama ja kun arvostelukin tapahtuu tavoitesuhteellisena, ei ole väliä sillä, missä jokin kurssi on suoritettu.

Tällä hetkellä on aikuiskoulutusjärjestelmällä erittäin tärkeä tehtävä niin yleissivistävän koulutuksen kuin myös ammatillisen koulutuksen alueella. Tämä toiminta on erittäin tärkeätä erityisesti nyt, kun ollaan siirtymässä uudistuvaan keskiasteen koulutuksen järjestelmään. Tässä siirtymävaiheessa jää hyvin monelle monenlaisia koulutusaukkoja, jotka aikuiskoulutuksen tulee paikata. Samanaikaisesti pitää kehittää aikuiskoulutusjärjestelmää, joka kytkeytyy ja niveltyy uudistuvaan keskiasteen peruskoulutukseen.

Lopuksi haluan esittää kolme teesiä, joita olen itse pitänyt ohjenuoranani. Ensimmäinen on: 'Jalat maassa"'. Se tarkoittaa sitä, että meidän on toimittava tässä ja nyt niillä resursseilla, joita meillä on ja meidän on tehtävä sitä, mitä pystymme. Toinen teesi kuuluu: "Valitaan kahdesta pahasta pienempi"'. Harvoin me voimme toteuttaa mielestämme parhaan ratkaisun, joten täytyy tyytyä kompromissiin. Kolmasti haluaisin korostaa laajasti huumorin merkitystä ihmiselle. Olen tämän muotoillut teesiksi: "Vapaasti mutta silti arvokkaasti"'. Humanistisena teknokraattina haluaisin lopuksi korostaa kaikessa toiminnassa ihmisyyttä ja epäitsekkyyttä. 